\title{
Spatial Scale Patterns of Genetic Diversity and Gene Flow in Populations of Sweet Detar (Detarium microcarpum Guill. \& Perr.; Fabaceae)
}

Relique Ignace AGBO ( $\square$ agbosiram@gmail.com )

Universite d'Abomey-Calavi Faculte des Sciences et Techniques

Antoine Missihoun

Universite d'Abomey-Calavi Faculte des Sciences et Techniques

David Montcho

Universite d'Abomey-Calavi Faculte des Sciences et Techniques

Rollande Dagba

Universite d'Abomey-Calavi Faculte des Sciences et Techniques

Paulin Sédah

Universite d'Abomey-Calavi Faculte des Sciences et Techniques

Clément Agbangla

Universite d'Abomey-Calavi Faculte des Sciences et Techniques

\section{Research Article}

Keywords: Benin, cpDNA, genetic differentiation, microsatellite markers, phylogenetic relationship, sweet dattock

Posted Date: September 7th, 2021

DOl: https://doi.org/10.21203/rs.3.rs-879012/v1

License: (ㅇ) (i) This work is licensed under a Creative Commons Attribution 4.0 International License. Read Full License 


\section{Abstract}

The main objective of this study is to investigate the patterns of genetic diversity and phylogenetic relationships within populations of Detarium microcarpum (Fabaceae) relative to different spatial conditions. Seventy-eight (78) accessions of D. microcarpum belonging to six populations (Phytogeographic districts) were sampled. In order to have very good quality DNA for molecular analysis, an optimization of the DNA isolation protocol was made. The molecular analysis of the accessions was carried out using 7 chloroplast microsatellite markers. The polymorphism rate $(P)$ is $85.71 \%$ and the Polymorphism Information Content (PIC) was in the range of 0.43 (Ntcp_9) to 0.73 (Ccmp_2) with an average of 0.59. Allelic richness (A) ranged from 1.41 to 2.85 with an average of 2.04. The observed heterozygosity $(\mathrm{Ho})$ ranged from 0.23 to 0.60 with an average of 0.39 . The expected heterozygosity $(\mathrm{He})$ ranged from 0.43 to 0.60 with a mean of 0.50 . Wright's fixation index $\left(F_{I S}\right)$ ranged from -0.17 to 0.47 . The effective allele $(\mathrm{Ae})$ is between 1.77 and 2.53 with an average of 2.02. Wright differentiation index $\left(\mathrm{F}_{S T}\right)$ was 0.024 . Phylogenetic analysis revealed that the $\mathrm{N}_{\mathrm{ST}}$ value was significantly higher than the $G_{S T}$ value $\left(N_{S T}=0.452 ; G_{S T}=0.190 ; P<0.05\right)$. A relatively low $h_{d}$ haplotype diversity is obtained $\left(H_{d}=\right.$ 0.320). AMOVA analysis showed that $17.35 \%$ of the variation existed within populations but $45.80 \%$ among populations within the species. Neighbor-Joining phylogenetic tree of $D$. microcarpum revealed three nondistinct clusters haplotypes showing the existence of gene flow between populations of the species. Our findings of genetic structure and gene flow of $D$. microcarpum populations based on different spatial conditions is caused by evolutionary forces such as scattering and pollination.

\section{Introduction}

Detarium microcarpum Guill. \& Perr. (Fabaceae) is a diploid forest plant species ( $2 n=22$ chromosomes) used in human and animal nutrition, traditional medicine, crafts, household energy and also for medico-magic purposes (Kouyaté 2005; Agbo et al. 2019a). It is involved in the treatment of several diseases including sexually transmitted diseases (Nacoulma 1996). The flavonoids in methanol extracts of the plant have been shown to have potent inhibitory effects on HIV-1 or HIV-2 infection (Mahmood 1993; Doulougou 2002; Nikiema et al. 2010). Detarium microcarpum (sweet dattock or sweet detar) therefore constitutes an important source of income for the local communities which exploit its resources daily for their needs.

Unfortunately, due to overexploitation of its timber and the effects of climate change, the species has become vulnerable in parts of West Africa (Adjahossou et al. 2016; Agbo et al. 2017). It is therefore urgent to develop strategies for its conservation in order to avoid its disappearance. The conservation of a forest species requires knowing the information about the level of genetic diversity and the extent of genetic differentiation within and between natural populations of that species (Assogbadjo et al. 2010). Several studies have been carried out on systematics and parataxonomy (Calvin 2007; Houénon et al. 2021), ethnobotany (Kouyaté et al. 2009; Agbo et al. 2019a), spatial and temporal distribution (Agbo et al. 2019b), phenology (Kouyaté 2005), morphological variability (Kouyaté 2005; Agbo et al. 2018) and pharmacology (Sani et al. 2014) of D. microcarpum. However, studies relating to the assessment of its genetic diversity using molecular genetic markers remain unavailable. Furthermore, knowledge of the level of genetic diversity and of the population structure of a plant is one of the very important aspects in programs for the management, conservation or genetic improvement of genetic resources (Missihoun et al. 2015; Jahan et al. 2020). 
The development of effective strategies for the conservation and sustainable management of forest genetic resources requires an analysis of the diversity and genetic structure of these plant species which requires the use of highly informative genetic molecular markers (Liu et al. 2012). DNA molecular markers, including RAPD (Ercisli et al. 2008; Vanijajiva 2011), AFLP (Schenk et al. 2008; Assogbadjo et al. 2010) and RFLP (Bhattacharjee et al. 2002; Yan et al. 2005), were used to assess genetic diversity at the molecular level of many populations of plant species. In recent years, microsatellite markers (SSR) have become popular and powerful tools used for the assessment of genetic diversity due to their codominance, high rate of polymorphism, and putative influence on transcribed genes (Benemann et al. 2012; Huda et al. 2019; Karam et al. 2019). Several nuclear microsatellite markers (SSRs) have been used to assess the genetic diversity of many plant species in Benin, including Sorghum bicolor (Missihoun et al. 2015), Pentadesma butyracea Sabine (Houédjissin 2016), Pennissetum glaucum (Dagba et al. 2018), etc. In addition, SSRs markers developed on chloroplast genomes (SSRcp) constitute a powerful tool in the analysis of phylogenetic relationships because they provide information on the structure of variability and allow the flow of genes to be traced back to the scale of the natural area (Andrianoelina Andrianaivo 2009; de Cesare et al. 2010; Phumichai et al. 2015). They make it possible to assess the impact of Human and animal activities on the diversity of species at the level of populations and sub-populations studied (Nanema et al. 2010; Vihotogbé et al. 2015). As of today, no molecular genetic marker have been developed on D. microcarpum. Genetic characterization and assessment of the genetic diversity of a species involves the extraction of the genomic DNA of that species. However, DNA extraction kits are very expensive and their use requires expertise. Hence the need for the establishment of a DNA extraction protocol. The effectiveness of DNA isolation protocols depends not only on the type of plant (woody or not) of the organ serving as biological material (leaves, root, flower, etc.) and on its state of conservation, but also of the chemical composition of the biological material; which means that several protocols have to be tested in order to retain the ideal (Chabi Sika et al. 2015; Adjé et al. 2016).

The objective of this study is to investigate the patterns of genetic diversity and phylogenetic relationships within populations of Detarium microcarpum relative to different spatial conditions.

\section{Materials And Methods}

Plant material sampling - The plant material consists of seventy-eight (78) samples of young leaves of $D$. microcarpum (taken from 78 trees) collected in six (06) phytogeographic districts in Benin (Bassila, Zou, South Borgou, North Borgou, Atacora Chain and Mekrou-Pendjari), at the rate of thirteen (13) trees per phytogeographic districts, spaced at least 50 meters apart. These phytogeographic districts belong to Sudanian and Guineo-Sudanian and were chosen on the basis of the occurrence of natural stands of the species (Fig. 1; Table 1) (Agbo et al. 2019b). Samples are georeferenced using a GPS and those belonging to the same phytogeographic district are considered to be from the same population (Table 2). 
Table 1

Ecological characterization of the climatic zone of sampling area.

\begin{tabular}{|c|c|c|c|c|c|}
\hline $\begin{array}{l}\text { Phytogeographic } \\
\text { district }\end{array}$ & $\begin{array}{l}\text { Climatic } \\
\text { zone }\end{array}$ & $\begin{array}{l}\text { Rainfall } \\
\text { regime }\end{array}$ & $\begin{array}{l}\text { Rainfall } \\
(\mathrm{mm})\end{array}$ & Major soil types & $\begin{array}{l}\text { Major plant } \\
\text { formation }\end{array}$ \\
\hline Bassila & $\begin{array}{l}\text { Guineo- } \\
\text { Sudanian }\end{array}$ & $\begin{array}{l}\text { Tendency } \\
\text { to } \\
\text { unimodal }\end{array}$ & $\begin{array}{l}\text { Min: } \\
1100 \\
\text { Max: } \\
1300\end{array}$ & $\begin{array}{l}\text { Ferrallitic soils with } \\
\text { concretions and } \\
\text { breastplates }\end{array}$ & $\begin{array}{l}\text { Semi-deciduous } \\
\text { forest, woodland, } \\
\text { and riparian forest }\end{array}$ \\
\hline $\begin{array}{l}\text { Zou } \\
\text { South Borgou }\end{array}$ & & & $\begin{array}{l}\text { Min: } \\
1100 \\
\text { Max: } \\
1200\end{array}$ & $\begin{array}{l}\text { Ferruginous soils on } \\
\text { crystalline rocks }\end{array}$ & $\begin{array}{l}\text { Dry forest, } \\
\text { woodland, and } \\
\text { riparian forest }\end{array}$ \\
\hline North Borgou & Sudanian & Unimodal & Min: & & \\
\hline Atacora Chain & & $\begin{array}{l}\text { (1 rainy } \\
\text { season) }\end{array}$ & $\begin{array}{l}\text { Max: } \\
1200\end{array}$ & $\begin{array}{l}\text { Poorly evolved \& mineral } \\
\text { soils }\end{array}$ & $\begin{array}{l}\text { Riparian forest, dry } \\
\text { forest, and } \\
\text { woodland }\end{array}$ \\
\hline Mekrou- Pendjari & & & $\begin{array}{l}\text { Min: } 900 \\
\text { Max: } \\
1000\end{array}$ & $\begin{array}{l}\text { Ferruginous soils with } \\
\text { concretions on } \\
\text { sedimentary rocks }\end{array}$ & $\begin{array}{l}\text { Tree and Shrub } \\
\text { savannahs, dry } \\
\text { forest and riparian } \\
\text { forest }\end{array}$ \\
\hline
\end{tabular}


Table 2

Study site and geographic coordinates for the sample of D. microcarpum populations.

\begin{tabular}{|c|c|c|c|c|c|c|c|}
\hline \multirow[t]{2}{*}{ Identifiers } & \multicolumn{2}{|l|}{$\begin{array}{l}\text { Geographic } \\
\text { coordinates }\end{array}$} & \multirow{2}{*}{$\begin{array}{l}\text { Population } \\
\text { (Population } \\
\text { id) }\end{array}$} & \multirow[t]{2}{*}{ Identifiers } & \multicolumn{2}{|l|}{$\begin{array}{l}\text { Geographic } \\
\text { coordinates }\end{array}$} & \multirow{2}{*}{$\begin{array}{l}\text { Population } \\
\text { (Population } \\
\text { id) }\end{array}$} \\
\hline & Lat $(\mathrm{N})$ & Long (E) & & & Lat (N) & Long (E) & \\
\hline BaBa174 & $9^{\circ} 24.197^{\prime}$ & $1^{\circ} 35.042^{\prime}$ & \multirow{13}{*}{$\begin{array}{l}\text { Bassila } \\
\text { (BA) }\end{array}$} & CaBo148 & $10^{\circ} 10.449^{\prime}$ & $1^{\circ} 11.949^{\prime}$ & \multirow{13}{*}{$\begin{array}{l}\text { Atacora } \\
\text { chain } \\
(A C)\end{array}$} \\
\hline BaBa176 & $9^{\circ} 21.467^{\prime}$ & $1^{\circ} 33.965^{\prime}$ & & CaBo154 & $10^{\circ} 10.311^{\prime}$ & $1^{\circ} 11.711^{\prime}$ & \\
\hline BaBa179 & $9^{\circ} 12.073^{\prime}$ & $1^{\circ} 33.985^{\prime}$ & & CaKe101 & $10^{\circ} 56.886^{\prime}$ & $2^{\circ} 12.880^{\prime}$ & \\
\hline BaBa180 & $8^{\circ} 57.805^{\prime}$ & $1^{\circ} 39.095^{\prime}$ & & CaKe102 & $10^{\circ} 56.175^{\prime}$ & $2^{\circ} 11.869^{\prime}$ & \\
\hline BaBn184 & $8^{\circ} 36.667^{\prime}$ & $1^{\circ} 40.691^{\prime}$ & & CaKe103 & $10^{\circ} 56.643^{\prime}$ & $2^{\circ} 12.135^{\prime}$ & \\
\hline BaBn188 & $8^{\circ} 16.007^{\prime}$ & $1^{\circ} 57.712^{\prime}$ & & CaKo155 & $10^{\circ} 18.278^{\prime}$ & $1^{\circ} 39.151^{\prime}$ & \\
\hline BaCo114 & $9^{\circ} 49.548^{\prime}$ & $1^{\circ} 33.283^{\prime}$ & & CaKo158 & $10^{\circ} 19.672^{\prime}$ & $1^{\circ} 42.664^{\prime}$ & \\
\hline BaCo116 & $9^{\circ} 52.274^{\prime}$ & $1^{\circ} 32.090^{\prime}$ & & CaNa119 & $10^{\circ} 02.685^{\prime}$ & $1^{\circ} 29.240^{\prime}$ & \\
\hline BaCo117 & $9^{\circ} 56.263^{\prime}$ & $1^{\circ} 31.824^{\prime}$ & & CaNa122 & $10^{\circ} 10.972^{\prime}$ & $1^{\circ} 24.796^{\prime}$ & \\
\hline BaDj164 & $9^{\circ} 41.364^{\prime}$ & $1^{\circ} 35.958^{\prime}$ & & CaNa124 & $10^{\circ} 21.805^{\prime}$ & $1^{\circ} 21.151^{\prime}$ & \\
\hline BaDj167 & $9^{\circ} 41.877^{\prime}$ & $1^{\circ} 30.041^{\prime}$ & & CaNa145 & $10^{\circ} 25.105^{\prime}$ & $1^{\circ} 21.715^{\prime}$ & \\
\hline BaDj169 & $9^{\circ} 40.455^{\prime}$ & $1^{\circ} 41.667^{\prime}$ & & СaTo126 & $10^{\circ} 28.387^{\prime}$ & $1^{\circ} 22.130^{\prime}$ & \\
\hline BaDj170 & $9^{\circ} 39.701^{\prime}$ & $1^{\circ} 42.187^{\prime}$ & & CaTo130 & $10^{\circ} 29.293^{\prime}$ & $1^{\circ} 22.543^{\prime}$ & \\
\hline BnBe63 & $9^{\circ} 50.575^{\prime}$ & $2^{\circ} 59.107^{\prime}$ & \multirow{13}{*}{$\begin{array}{l}\text { North } \\
\text { Borgou } \\
\text { (NB) }\end{array}$} & MpBa100 & $11^{\circ} 15.101^{\prime}$ & $2^{\circ} 38.385^{\prime}$ & \multirow{13}{*}{$\begin{array}{l}\text { Mekrou- } \\
\text { Pendjari } \\
\text { (MP) }\end{array}$} \\
\hline BnBe64 & $10^{\circ} 00.937^{\prime}$ & $2^{\circ} 40.142^{\prime}$ & & MpBa97 & $11^{\circ} 18.339^{\prime}$ & $2^{\circ} 31.929^{\prime}$ & \\
\hline BnGo78 & $10^{\circ} 54.550^{\prime}$ & $2^{\circ} 51.288^{\prime}$ & & MpCo138 & $10^{\circ} 28.515^{\prime}$ & $1^{\circ} 02.096^{\prime}$ & \\
\hline BnKa111 & $10^{\circ} 40.175^{\prime}$ & $3^{\circ} 34.961^{\prime}$ & & MpCo139 & $10^{\circ} 30.047^{\prime}$ & $1^{\circ} 00.575^{\prime}$ & \\
\hline BnKa112 & $11^{\circ} 38.037^{\prime}$ & $3^{\circ} 34.894^{\prime}$ & & MpCo142 & $10^{\circ} 33.703^{\prime}$ & $0^{\circ} 59.623^{\prime}$ & \\
\hline BnKa113 & $10^{\circ} 28.458^{\prime}$ & $3^{\circ} 32.159^{\prime}$ & & MpMa143 & $11^{\circ} 44.326^{\prime}$ & $3^{\circ} 13.268$ & \\
\hline BnKa81 & $11^{\circ} 05.820^{\prime}$ & $2^{\circ} 59.740^{\prime}$ & & MpMa144 & $11^{\circ} 41.418^{\prime}$ & $3^{\circ} 12.490^{\prime}$ & \\
\hline BnKa83 & $11^{\circ} 05.552^{\prime}$ & $3^{\circ} 00.054^{\prime}$ & & MpMa85 & $11^{\circ} 40.966^{\prime}$ & $3^{\circ} 12.099^{\prime}$ & \\
\hline BnPe161 & $10^{\circ} 14.913^{\prime}$ & $1^{\circ} 53.586^{\prime}$ & & MpMa88 & $11^{\circ} 39.939^{\prime}$ & $3^{\circ} 11.739^{\prime}$ & \\
\hline BnSe105 & $10^{\circ} 57.214^{\prime}$ & $3^{\circ} 25.377^{\prime}$ & & MpMa91 & $11^{\circ} 32.960^{\prime}$ & $3^{\circ} 07.250^{\prime}$ & \\
\hline BnSe108 & $10^{\circ} 50.773^{\prime}$ & $3^{\circ} 38.025^{\prime}$ & & MpMa94 & $11^{\circ} 30.346^{\prime}$ & $3^{\circ} 06.257^{\prime}$ & \\
\hline BnSi70 & $10^{\circ} 16.518^{\prime}$ & $2^{\circ} 27.544^{\prime}$ & & МpТa132 & $10^{\circ} 37.822^{\prime}$ & $1^{\circ} 17.967^{\prime}$ & \\
\hline BnSi73 & $10^{\circ} 21.275^{\prime}$ & $2^{\circ} 23.450^{\prime}$ & & MpTa135 & $10^{\circ} 39.378^{\prime}$ & $1^{\circ} 14.613^{\prime}$ & \\
\hline $\begin{array}{l}\text { RsNd.54 } \\
\text { Loading [Math }\end{array}$ & $\begin{array}{l}9^{\circ} 44.539^{\prime} \\
\text { ax//jax/output/ }\end{array}$ & $\begin{array}{l}2^{\circ} 41790^{\prime} \\
\text { nmonHTML/jar }\end{array}$ & $\begin{array}{l}\text { South } \\
\text { js prgou }\end{array}$ & ZoDa28 & $7^{\circ} 48.352^{\prime}$ & $2^{\circ} 10.954^{\prime}$ & Zou \\
\hline
\end{tabular}




\begin{tabular}{|c|c|c|c|c|c|c|c|}
\hline BsNd56 & $9^{\circ} 44.550^{\prime}$ & $2^{\circ} 41.753^{\prime}$ & \multirow[t]{12}{*}{ (SB) } & ZoDa29 & $7^{\circ} 59.986^{\prime}$ & $2^{\circ} 26.874^{\prime}$ & \multirow[t]{12}{*}{ (ZO) } \\
\hline BsNi57 & $9^{\circ} 54.184^{\prime}$ & $2^{\circ} 55.997^{\prime}$ & & ZoDa30 & $7^{\circ} 57.564^{\prime}$ & $2^{\circ} 28.336^{\prime}$ & \\
\hline BsNi58 & $9^{\circ} 49.231^{\prime}$ & $2^{\circ} 59.327^{\prime}$ & & ZoDj1 & $7^{\circ} 30.848^{\prime}$ & $2^{\circ} 05.411^{\prime}$ & \\
\hline BsOu35 & $8^{\circ} 28.530^{\prime}$ & $2^{\circ} 26.392^{\prime}$ & & ZoDj2 & $7^{\circ} 31.037^{\prime}$ & $2^{\circ} 05.459^{\prime}$ & \\
\hline BsPa51 & $9^{\circ} 20.206^{\prime}$ & $2^{\circ} 36.978^{\prime}$ & & ZoDj3 & $7^{\circ} 31.511^{\prime}$ & $2^{\circ} 04.566^{\prime}$ & \\
\hline BsPa52 & $9^{\circ} 20.132$ & $2^{\circ} 34.349^{\prime}$ & & ZoDj6 & $7^{\circ} 31.546^{\prime}$ & $2^{\circ} 04.507^{\prime}$ & \\
\hline BsPe61 & $9^{\circ} 50.008^{\prime}$ & $2^{\circ} 59.302^{\prime}$ & & ZoDj13 & $7^{\circ} 29.755^{\prime}$ & $1^{\circ} 59.643^{\prime}$ & \\
\hline BsTc41 & $8^{\circ} 23.426^{\prime}$ & $2^{\circ} 29.306^{\prime}$ & & ZoDj15 & $7^{\circ} 29.771^{\prime}$ & $1^{\circ} 59.635^{\prime}$ & \\
\hline BsTc42 & $8^{\circ} 52.915^{\prime}$ & $2^{\circ} 34.969^{\prime}$ & & ZoDj23 & $7^{\circ} 29.520^{\prime}$ & $1^{\circ} 59.889^{\prime}$ & \\
\hline BsTc47 & $8^{\circ} 54.157^{\prime}$ & $2^{\circ} 35.799^{\prime}$ & & ZoGl31 & $8^{\circ} 01.233^{\prime}$ & $1^{\circ} 59.083^{\prime}$ & \\
\hline BsTc49 & $8^{\circ} 55.208^{\prime}$ & $2^{\circ} 35.397^{\prime}$ & & ZoSI187 & $7^{\circ} 55.353^{\prime}$ & $2^{\circ} 00.811^{\prime}$ & \\
\hline BsTc50 & $9^{\circ} 02.079^{\prime}$ & $2^{\circ} 36.925^{\prime}$ & & ZoSa34 & $8^{\circ} 28.551^{\prime}$ & $2^{\circ} 26.384^{\prime}$ & \\
\hline
\end{tabular}

Optimization of genomic DNA isolation protocol of D. microcarpum - Molecular Genetics and Genome Analysis Laboratory of University of Abomey-Calavi (Benin) served as a study setting for molecular analysis of $D$. microcarpum samples. Several genomic DNA isolation protocols (Table 3) were tested on different quantities of young fresh leaves $(0.1 \mathrm{~g}, 0.15 \mathrm{~g}$ and $0.2 \mathrm{~g})$ on the one hand and on dry young leaves on the other hand of $D$. microcarpum. The composition of the isolation buffer was adjusted in order to find the appropriate protocol, relatively fast, inexpensive and allowing an average yield of good quality genomic DNA. 
Table 3

Composition of the buffer solutions of the different genomic DNA isolation protocols tested.

\begin{tabular}{|c|c|c|c|c|c|}
\hline $\begin{array}{l}\text { Protocol tested } \\
\text { Composition }\end{array}$ & $\begin{array}{l}\text { Dellaporta et } \\
\text { al. } 1983\end{array}$ & $\begin{array}{l}\text { Doyle \& } \\
\text { Doyle } 1987\end{array}$ & $\begin{array}{l}\text { Agbangla et } \\
\text { al. } 2002 \\
\text { (Dioscorea } \\
\text { spp.) }\end{array}$ & $\begin{array}{l}\text { Benbouza et } \\
\text { al. } 2006 \\
\text { (Gossypium } \\
\text { spp.) }\end{array}$ & $\begin{array}{l}\text { Adjé et al. } \\
2016 \\
\text { (Ananas } \\
\text { cormosus) }\end{array}$ \\
\hline MATAB (\%) & - & - & 4 & - & - \\
\hline CTAB (\%) & - & 2 & - & 2 & 2 \\
\hline $\begin{array}{l}\text { Tris- } \mathrm{HCl}(\mathrm{mM}), \mathrm{pH}= \\
8\end{array}$ & 100 & 100 & 100 & 100 & 500 \\
\hline $\mathrm{NaCl}(\mathrm{M})$ & 0.5 & 1.4 & 1.4 & 2 & 1.3 \\
\hline EDTA (mM) & 50 & 20 & 20 & 20 & 5 \\
\hline $\begin{array}{l}\text { Ammonium acetate } \\
(\mathrm{mM})\end{array}$ & - & - & - & 10 & - \\
\hline $\begin{array}{l}\text { Bmercapto ethanol } \\
(\%)\end{array}$ & 0.07 & 0.5 & - & 5 & 0.1 \\
\hline Charcoal (mg.g $\left.{ }^{-1}\right)$ & - & - & - & $10-15$ & - \\
\hline SDS & $20 \%$ & - & - & - & - \\
\hline $\begin{array}{l}\text { Incubation time at } \\
65^{\circ} \mathrm{C}(\min )\end{array}$ & 10 & 60 & 90 & 60 & 90 \\
\hline
\end{tabular}

DNA quantification - The DNA yield was estimated using a spectrophotometer at UV-VIS 230, 260 and $280 \mathrm{~nm}$. The purity of the DNA was determined by calculating the ratio A260/A280 nm to assess the protein contamination and A260/230 to assess polysaccharide contamination (Wilson and Walker 2010). The DNA concentration was calculated with the following formula: [DNA] = A260 x DF x $50 \mu \mathrm{g} / \mathrm{ml}$, where [DNA] is the DNA concentration, A260 is the Absorbance at $260 \mathrm{~nm}$, DF = Dilution Factor; $50 \mu \mathrm{g} / \mathrm{ml}$ is the Concentration of DNA when $A 260=1$.

DNA Amplification by Polymerase Chain Reaction (PCR) - Dilutions of the DNA extracts were made to obtain the concentrations necessary for the amplification of DNA by PCR. A concentration of around $150 \mathrm{ng} / \mu \mathrm{L}$ was obtained from the suspensions previously obtained after DNA extraction. To amplify sequences of the $D$. microcarpum DNA, seven (07) chloroplast microsatellite markers (SSRcp) out of the ten tested were used. These are six (06) Ntcp primers (Nicotiana tabacum chloroplast) developed on tobacco (Bryan et al. 1999) and a Ccmp (Consensus chloroplast microsatellite primers) primer, a universal primer developed by Weising and Gardner (1999). The primers used are: Ntcp_8, Ntcp_9, Ntcp_33, Ntcp_36, Ntcp_37, Ntcp_39 and Ccmp_2 (Table 4). These primers have been used successfully on other speculations such as Helianthus annuus (Wills et al. 2005), Solenostemon rotundifolius (Nanema et al. 2010) and Solanum tuberosum (Zeka et al. 2014). Microsatellite primers from intergenic regions, introns and exons were used to assess the variability of the chloroplast DNA of $D$. microcarpum from the collection studied. Twenty two microliters (22 $\mu \mathrm{L})$ of PCR master mix composed of $200 \mu \mathrm{M}$ dNTP; $0.2 \mu \mathrm{M}$ of each primer (forward and reverse); $1.25 \mu \mathrm{M}$ of $\mathrm{MgCl} 2 ; 0.1 \mathrm{U} / \mu \mathrm{L}$ of Loading [MathJax]/jax/output/CommonHTML/jax.js ffer and $9.25 \mu \mathrm{L}$ of ultrapure water were added to $3 \mu \mathrm{L}$ of DNA 
(approximately $3 \mathrm{ng} / \mu \mathrm{L}$ ) of each sample. A Programmable thermal Blok II thermal cycler was used for amplification. The cycle of amplification included a pre-denaturation at $94^{\circ} \mathrm{C}$ for 4 min followed by 35 cycles, each cycle consisted of a denaturation at $94^{\circ} \mathrm{C}$ for $30 \mathrm{~s}$, hybridization in the appropriate temperature $\left(50^{\circ} \mathrm{C}\right.$ or $60^{\circ} \mathrm{C}$, Table 4) for $1 \mathrm{~min}$ and an elongation at $72^{\circ} \mathrm{C}$ for $1 \mathrm{~min}$. A final incubation at $72^{\circ} \mathrm{C}$ for 8 min ended the program. The effectiveness of the amplification was tested by electrophoresis on $2 \%$ agarose gel in $0.5 \mathrm{X}$ TBE buffer. Gels were run in horizontal gel system at $100 \mathrm{~V}$ for $30 \mathrm{~min}$ and later photographed under UV light after be stained with ethidium bromide (BET).

Table 4

Characteristics of the chloroplastic microsatellite primers.

\begin{tabular}{|c|c|c|c|c|c|c|c|}
\hline $\begin{array}{l}\text { SSRs } \\
\text { Loci }\end{array}$ & $\begin{array}{l}\text { Gene location } \\
\text { of } \\
\text { microsatellite } \\
\text { repeat(s) }\end{array}$ & $\begin{array}{l}\text { Repeat } \\
\text { unit }\end{array}$ & $\begin{array}{l}\text { Forward primer sequence }(F) \\
\text { Reverse primer sequence }(R)\end{array}$ & $\begin{array}{l}\mathrm{Ta} \\
(\cdot \mathrm{C})\end{array}$ & $\begin{array}{l}\text { Size in } \\
N . \\
\text { tabacum } \\
\text { (pb) }\end{array}$ & PIC & $\mathrm{Na}$ \\
\hline \multirow[t]{2}{*}{ Ntcp_8 } & trnG intron & $\mathrm{T} 11$ & F: ATATTGTTTTAGCTCGGTGG & 55 & 251 & 0.52 & 3 \\
\hline & & & R: TCATTCGGCTCCTTTATG & & & & \\
\hline \multirow[t]{2}{*}{ Ntcp_9 } & $\operatorname{trnG} / \operatorname{trnR}$ & $\mathrm{T} 10$ & F: CTTCCAAGCTAACGATGC & 55 & 237 & 0.43 & 2 \\
\hline & $\begin{array}{l}\text { intergenic } \\
\text { region }\end{array}$ & & $\begin{array}{l}\text { R: } \\
\text { CTGTCCTATCCATTAGACAATG }\end{array}$ & & & & \\
\hline \multirow[t]{2}{*}{ Ntcp_33 } & rpoA exon & $\mathrm{T} 10$ & F: TGGCTGTTATTCAAAAGGTC & 60 & 149 & - & 1 \\
\hline & & & $\begin{array}{l}\text { R: } \\
\text { CATGATAAATTGGCTAAACTCA }\end{array}$ & & & & \\
\hline \multirow[t]{2}{*}{ Ntcp_36 } & $\begin{array}{l}\text { rps } 19 / \mathrm{rpl} / 2 \\
\text { intergenic }\end{array}$ & T14 & $\begin{array}{l}\text { F: } \\
\text { GTAGTAAATAGGAGAGAAAATAG }\end{array}$ & 50 & 125 & 0.59 & 3 \\
\hline & & & R: ATGATACATAGTGCGATACAG & & & & \\
\hline \multirow[t]{2}{*}{ Ntcp_37 } & rrn5/trnR & A13 & F: TTCCGAGGTGTGAAGTGG & 55 & 143 & 0.65 & 3 \\
\hline & region & & $\begin{array}{l}\text { R: } \\
\text { CAGGATGATAAAAAGCTTAACAC }\end{array}$ & & & & \\
\hline \multirow[t]{2}{*}{ Ntcp_39 } & $\begin{array}{l}\operatorname{trnR} / \mathrm{rrn} 5 \\
\text { intergenic }\end{array}$ & $\mathrm{T} 13$ & $\begin{array}{l}\text { F: } \\
\text { GTCACAATTGGGGTTTTGAATA }\end{array}$ & 60 & 156 & 0.64 & 3 \\
\hline & & & $\begin{array}{l}\text { R: } \\
\text { GACGATACTGTAGGGGAGGTC }\end{array}$ & & & & \\
\hline \multirow[t]{2}{*}{ Ccmp_2 } & $5^{\prime}$ to trnS & A11 & F: GATCCCGGACGTAATCCTG & 60 & 189 & 0.73 & 7 \\
\hline & region & & R: ATCGTACCGAGGGTTCGAAT & & & & \\
\hline
\end{tabular}

Electrophoresis and revelation of PCR amplification products - The determination of the polymorphism at each locus was carried out by migration of the PCR amplification products by electrophoresis in $5 \%$ denaturing Loading [MathJax]/jax/output/CommonHTML/jax.js 
polyacrylamide gel of $305 \times 385 \mathrm{~mm}$ ( $5 \%$ acrylamide-bisacrylamide (19:1), $8 \mathrm{~mol}$ urea in Tris-borate-EDTA/L (TBE) buffer, $\mathrm{pH} 8$ ) at constant power of $60 \mathrm{~W}$ for $1 \mathrm{~h} 30 \mathrm{~min}$ to $2 \mathrm{~h}$, depending on the expected product size. The detection of electrophoretic plates was carried out with silver nitrate $\left(\mathrm{AgNO}_{3}\right)$ according to Creste et al. (2001). The different bands or allelic level are determined by scoring as a function of the level of migration of the bands obtained.

Data analysis - The bands obtained at each locus were recorded as allelic compositions: absence and presence of band were respectively coded as 0 and 1 . A binary matrix was constructed for statistical analysis.

To analyze the effectiveness of the microsatellite markers used in characterizing D. microcarpum populations, polymorphism rate $(P)$ and Polymorphism Information Content (PIC) were calculated. In order to assess the genetic differentiation and the genetic structure within and between populations of $D$. microcarpum, following genetic diversity and structure parameters are calculated: Allelic richness (A), Effective allele (Ae), Expected heterozygosity $(\mathrm{He})$, Observed heterozygosity $(\mathrm{Ho})$, Wright's fixation index $\left(\mathrm{F}_{\mathrm{IS}}\right)$ and Wright's differentiation index $\left(\mathrm{F}_{\mathrm{ST}}\right)$.

Polymorphism rate $(P)$ is the quotient of the number of polymorphic markers $(\mathrm{Mp})$ over the total number of markers (Mt): $\mathrm{P}=\mathrm{Mp} / \mathrm{Mt} \times 100$. A population is polymorphic for a locus, if the allelic frequency of the most frequent allele is less than 0.95 (Dagba et al. 2018).

Polymorphism Information Content of (PIC) was computed by the formula: $\mathrm{PIC}=1-\sum \mathrm{fi}^{2}$ where $\mathrm{fi}$, the allele frequency. It provides information on the discriminating power of the locus (Botstein et al. 1980; Missihoun et al. 2015). Allelic richness (A) is the sum of alleles for a locus over the total number of loci. It is determined by the formula: $A=(1 / k) \sum_{n=1}^{k}$ niwhere $k$ is the total number of loci and $n i$ the number of allele per locus (Bhandari et al. 2017). Allelic richness is particularly important for conservation strategies because it is often used in the management of collections and seed banks (Bataillon et al. 1996). Effective allele number (Ae) was computed by the formula: $A e=1 / \otimes\left(f_{i}\right)^{2}$ where $f i$ is the allele frequency. It provides information about the dispersal ability of the organism and the degree of isolation among populations (Kremer 1994; Govindaraj et al. 2015). Rate of expected heterozygosity $(\mathrm{He})$ or genetic diversity of Nei was calculated by locus according to the formula: $\mathrm{He}=1-\sum(\mathrm{fi})^{2}$, where $f i$ is the frequency of the allele $i$ at the considered locus (Nei 1987). The average expected heterozygosity rate of the loci was calculated by population and also by chromosomal region, in order to determine the level of genetic variability of the microsatellite sequences of the coding and non-coding regions of the cpDNA of D. microcarpum (Zeka et al. 2015). Rate of observed heterozygosity (Ho) was calculated from the measured frequency of heterozygotes by:

$\mathrm{Ho}=\mathrm{Nh} /(\mathrm{Nt})$ where $\mathrm{N} h$ is the number of heterozygous individuals and $\mathrm{Nt}$ the total number of individuals (Nei 1987). By comparing these two indices ( $\mathrm{He}$ and $\mathrm{Ho}$ ), it is possible to deduce the impact of evolutionary forces in populations, due to self-fertilization or autogamy. Wright fixation Index $\left(F_{I S}\right)$ was calculated from the allele frequencies under the Hardy-Weinberg hypothesis according to the formula: $F_{I S}=1$ - ( $\left.\mathrm{Ho} / \mathrm{He}\right)$. It reflects the differentiation of individuals within populations. $F_{I S}=1$ mean complete fixation (self-fertilization), $F_{I S}<1$ : excess heterozygosity, $F_{I S}=0$ : Hardy-Weinberg equilibrium population. $F_{I S}<0$ : excess heterozygosity (Wright 1978; Govindaraj et al. 2015). Wright differentiation index $\left(F_{S T}\right)$ is related to heterozygosity and genetic drift. Since

Loading [MathJax]/jax/output/CommonHTML/jax.js zygotes, as a consequence, it decreases the frequency of 
heterozygotes and genetic diversity. It is commonly used to determine whether there is gene flow between populations. It is obtained with the following formula: $\mathrm{F}_{\mathrm{ST}}=1-\left(\mathrm{H}_{\mathrm{S}} / \mathrm{H}_{\mathrm{T}}\right)$. Where $H_{\mathrm{S}}$ is the average $\mathrm{He}$ of subpopulations assuming random mating within each population, and $H_{\mathrm{T}}$ is the $\mathrm{He}$ of the total population assuming random mating within subpopulations and no divergence of allele frequencies among subpopulations. According to Wright (1978), $0<\mathrm{F}_{\mathrm{ST}}<0.05$ : weak differentiation; $0.05<\mathrm{F}_{\mathrm{ST}}<0.15$ : moderate differentiation; $0.15<\mathrm{F}_{\mathrm{ST}}<0.25$ : significant differentiation; $\mathrm{F}_{\mathrm{ST}}>0.25$ : very important differentiation. In order to establish the phylogenetic relationship within populations of $D$. microcarpum with a quantification of gene flow in its populations, the program PermutCpSSR_1.2.1 (Pons \& Petit, 1996) was used to calculate the level of population differentiation at the species level $\left(\mathrm{G}_{\mathrm{ST}}\right)$, and an estimate of population subdivisions for phylogenetically ordered alleles $\left(\mathrm{N}_{\mathrm{ST}}\right) . \mathrm{G}_{\mathrm{ST}}$ and $\mathrm{N}_{\mathrm{ST}}$ are often used to assess the geographical structure affecting population differentiation (Sun et al. 2019). If there is a phylogenetically matched haplotype, the closest haplotypes are more often found mixed in the same populations. Differentiation measured by taking into account similarities between haplotypes $\left(N_{S T}\right)$ is superior to differentiation based only on haplotype frequency $\left(\mathrm{G}_{\mathrm{ST}}\right.$ ). The analyses of molecular variance (AMOVA) in ARLEQUIN 3.5 (available at http://cmpg.unibe.ch/software/arlequin3/) were performed to calculate the genetic variation among populations and within populations, using a significance test based on 1,000 permutations (Excoffier \& Lischer, 2010). A classification of accessions was made from the genetic distance calculated by the dissimilarity coefficient of Jaccard with 1000 bootstraps repetitions and a dendrogram was built by the Neighbor-Joining method with DARwin version 6 software (Perrier \& Jacquemoud-Collet 2010).

\section{Results}

Genomic DNA isolation buffer of the new protocol - Table 3 showed the composition of the buffer solutions of the different genomic DNA isolation protocols tested. Genomic DNA isolation buffer of the new protocol is composed of: Chloroform Isoamylic Alcohol (24: 1), isopropanol, 70\% ethanol, Tris-EDTA (10 mM Tris-HCl, 1 $\mathrm{mM}$ EDTA) and $2 \%$ CTAB containing $2 \mathrm{~g}$ of CTAB, $1.4 \mathrm{M}$ of $\mathrm{NaCl}, 100 \mathrm{mM}$ of Tris-HCl $(1 \mathrm{M}, \mathrm{pH}=8), 20 \mathrm{mM}$ of EDTA $(0.5 \mathrm{M}, \mathrm{pH}=8)$ supplemented with $2 \% \beta$-Mercaptoethanol and $0.5 \%$ Proteinase $\mathrm{K}$ (added after sterilization and just before use in a hood).

New protocol for genomic DNA isolation from D. microcarpum - The new protocol resulted in cleaner, good quality DNA that was easily amplified by PCR (Fig. 3). This new protocol is described as follows: A quantity of $150 \mathrm{mg}$ of dry leaves per sample was weighed and ground in a porcelain mortar with $1 \mathrm{~mL}$ of CTAB buffer supplemented with $2 \% \beta$-Mercaptoethanol and $0.5 \%$ proteinase $\mathrm{K}$. The ground material obtained was poured into a $2 \mathrm{~mL}$ eppendorf tube, homogenized for a few minutes and then incubated in a water bath at $65^{\circ} \mathrm{C}$ with gentle stirring for $60 \mathrm{~min}$ with homogenizations every $10 \mathrm{~min} .1 \mathrm{~mL}$ of Chloroform Isoamylic Alcohol (CIA) buffer was added to the mixture after cooling followed by gentle stirring for $5 \mathrm{~min}$. The whole is centrifuged at $10,000 \mathrm{rpm}$ for $15 \mathrm{~min}$ at $4^{\circ} \mathrm{C}$ without brake (free deceleration). The upper phase aqueous supernatant is transferred to another $1.5 \mathrm{~mL}$ eppendorf tube to which an equal volume (approximately $1 \mathrm{~mL}$ ) of very cold isopropanol has been added to precipitate the DNA. In order to optimize the quantity of the DNA ball, an incubation is done at $-20^{\circ} \mathrm{C}$ for $30 \mathrm{~min}$. After this precipitation phase, the mixture was centrifuged at $10,000 \mathrm{rpm}$ for $10 \mathrm{~min}$. The supernatant was removed and on the pellet, $500 \mu \mathrm{L}$ of $70 \%$ ethanol was added and the mixture homocenized then left at ronm temnerature for $20 \mathrm{~min}$. The mixture was then centrifuged at 10,000 rpm for 10 Loading [MathJax]/jax/output/CommonHTML/jax.js 
min then the supernatant carefully emptied and the DNA pellet dried at room temperature on filter paper in order to remove the ethanol (Fig. 2). After drying, the DNA ball was taken up in $50 \mu \mathrm{L}$ of Tris-EDTA buffer. To be sure of the success of the DNA extraction, the DNA yield was estimated using a spectrophotometer at UV-VIS 230, 260 and $280 \mathrm{~nm}$, and $2 \mu \mathrm{L}$ of genomic DNA extract were visualized on a 1\% agarose gel stained with ethidium bromide (BET). After this confirmation, DNA samples were kept in a freezer at $-20^{\circ} \mathrm{C}$ for molecular analysis. The shape and the relative intensity of the agarose gel migration bands are well parallel to the DNA concentration values extracted for the different samples.

Genetic structure of D. microcarpum using SSR markers - Seven chloroplast microsatellite markers (Ntcp_8, Ntcp_9, Ntcp_33, Ntcp_36, Ntcp_37, Ntcp_39 and Ccmp_2) of ten tested for DNA amplification by PCR amplified D. microcarpum genome and were polymorphic except Ntcp_33 (which was monomorphic). Polymorphism rate (P) was so 85.71\%. Four out of ten (Ntcp_5, Ntcp_15, Ntcp_25 and Ntcp_26) of the primers developed on N. tabacum failed to amplify a specific region on cpDNA in $D$. microcarpum accessions. On the chloroplast genome of $N$. tabacum these primers amplify microsatellite loci at T14 (Ntcp_5), at A10 (Ntcp_15), at A13 (Ntcp_25) and at T10 (Ntcp_26) with bands whose size varies between 120 and 190 bp. In total, twenty-two (22) alleles were detected on the seven amplified chloroplast microsatellite loci on $D$. microcarpum genome. The number of alleles per locus (Na) varied from 1 (Ntcp_33) to 7 (Ccmp_2) with an average of 3.14. Major allele frequency varied from 0.12 (Ntcp_9) to 0.22 (Ntcp_37) with an average of 0.16 (Fig. 4). Ccmp_2 locus was the most polymorphic ( $\mathrm{Na}=7$ alleles) and the most discriminating ( $\mathrm{PIC}=0.73)$ while Ntcp_9 was the least polymorphic ( $\mathrm{Na}=2$ alleles) and the least discriminating (0.43) (Table 4). The Polymorphism Information Content (PIC) ranged from 0.43 to 0.73 with an average of 0.59 . Within the phytogeographic districts, the allelic richness $(A)$ varied from 1.41 (Bassila) to 2.86 (South Borgou) with an average of 2.04. The observed heterozygosity $(\mathrm{Ho})$ ranged from 0.23 (Bassila) to 0.60 (Atacora chain) with an average of 0.39 . The expected heterozygosity $(\mathrm{He})$ ranged from 0.43 (Bassila) to 0.60 (South Borgou) with an average of 0.50. Wright's fixation index $\left(F_{I S}\right)$ ranged from - 0.17 (Atacora chain) to 0.47 (Bassila). Effective allele (Ae) is between 1.77 (Bassila) and 2.53 (South Borgou) with an average of 2.02 (Table 5). 
Table 5

Genetic diversity of D. microcarpum populations in Benin.

\begin{tabular}{|c|c|c|c|c|c|c|}
\hline \multirow[t]{2}{*}{ Population } & \multirow[t]{2}{*}{$\mathbf{N}$} & \multirow[t]{2}{*}{ A } & \multirow[t]{2}{*}{$\mathrm{Ae}$} & \multicolumn{2}{|c|}{ Heterosigosity } & \multirow[t]{2}{*}{$F_{I S}$} \\
\hline & & & & Ho & $\mathrm{He}$ & \\
\hline$A C$ & 13 & 2.000 & 2.053 & 0.603 & 0.513 & -0.175 \\
\hline BA & 13 & 1.428 & 1.769 & 0.230 & 0.435 & 0.471 \\
\hline MP & 13 & 1.857 & 1.776 & 0.297 & 0.437 & 0.321 \\
\hline NB & 13 & 2.428 & 2.092 & 0.425 & 0.522 & 0.186 \\
\hline SB & 13 & 2.857 & 2.531 & 0.455 & 0.605 & 0.248 \\
\hline $\mathrm{ZO}$ & 13 & 1.714 & 1.923 & 0.324 & 0.480 & 0.325 \\
\hline Mean & 13 & 2.047 & 2.024 & 0.389 & 0.498 & 0.229 \\
\hline
\end{tabular}

Phylogenetic relationship and the level of gene flow in the populations of D. microcarpum Genetic variability of the microsatellite sequences in the coding and non-coding regions was estimated on the basis of their expected heterozygosity. Wright differentiation Index $\left(F_{S T}\right)$ is 0.024 . Phylogenetic analysis revealed that the $N_{S T}$ value was significantly higher than the $G_{S T}$ value $\left(N_{S T}=0.452 ; G_{S T}=0.190 ; P<0.05\right)$. A relatively low $h_{d}$ haplotype diversity is obtained $\left(H_{d}=0.320\right)$. AMOVA analysis showed that $17.35 \%$ of the variation existed within populations but $45.80 \%$ among populations within the species (Table 6). The classification of D. microcarpum accessions showed on the phylogenetic tree constructed by the Neighbor-Joining method three (03) non-distinct Haplotypes characterized by the presence of accessions from different populations (Fig. 5). The distribution of individuals was therefore not made according to the populations considered. There is a mixture of individuals from populations in each haplotype.

Table 6

AMOVA result for D. microcarpum populations from cpDNA haplotypes.

\begin{tabular}{|llllll|}
\hline $\begin{array}{l}\text { Source of } \\
\text { Variation }\end{array}$ & $\begin{array}{l}\text { Degree of } \\
\text { Freedom }\end{array}$ & $\begin{array}{l}\text { Sum of } \\
\text { Squares }\end{array}$ & $\begin{array}{l}\text { Variance } \\
\text { Components }\end{array}$ & $\begin{array}{l}\text { Percentage of } \\
\text { variation }\end{array}$ & $\begin{array}{l}\text { Palue } \\
\begin{array}{l}\text { Among } \\
\text { populations }\end{array}\end{array}$ \\
\hline $\begin{array}{l}\text { Within } \\
\text { populations }\end{array}$ & 14 & 50.175 & 3.246 & $45.80 \%$ & $\nabla 0.01$ \\
\hline
\end{tabular}

\section{Discussion}

Genomic DNA isolation of D. microcarpum: an essential step in genetic molecular analysis DNA isolation is a crucial and the first step of a DNA-based genetic characterization study. The quality and purity of nucleic acids are among the most critical factors for subsequent analysis. Like some plants including Ceratonia siliqua Loading [MathJax]/jax/output/CommonHTML/jax.js oseae very rich in secondary metabolites such as polysaccharides, 
polyphenols, tannins, proteins, etc. These secondary metabolisms can bind to the DNA molecule, making it difficult to extract and access enzymes (Lakshmi et al. 2002). This is why our first intentions and efforts in this study were concentrated on the development of an isolation technique capable of having a good quality of DNA which can be used as a template for the amplification of DNA by PCR. The deficiency of DNA isolation protocol adapted to Detarium microcarpum and the expensive cost of DNA extraction kits obliged us to test and modify some DNA isolation protocols including that of Dellaporta et al. (1983), Doyle and Doyle (1987), Benbouza et al. (2006), Adjé et al. (2016) using Cetyl Triammonium Bromide (CTAB) and that of Agbangla et al. (2002) using Mixed Alkyl Timethyl Ammonium Bromide (MATAB). The DNA isolation protocol set up by Dellaporta et al. (1983) and de Doyle and Doyle (1987) using CTAB are very efficient and commonly used to extract genomic DNA from woody plants (Dwivedi et al. 2001; Li \& Nelson 2002; Mongkolporn et al. 2003; Konaté 2007). However, their application to the leaf of $D$. microcarpum was inconclusive and the resulting bundle was either very viscous and insoluble or free from any trace of DNA. This led us to the various modifications to the protocol including the use of $\beta$-Mercaptoethanol and proteinase $\mathrm{K}$ considered as chemical agents having a positive and effective impact on the dissolution of the tannin-protein complex, responsible for the anchoring of several constituents cells of certain plants and the elimination of plant proteins (Konaté 2007). The results of the DNA sample verification testify to the efficiency and cost-effectiveness of the modified Doyle and Doyle (1987) protocol on D. microcarpum.

Amplification of cpDNA sequences by PCR - Chloroplast microsatellite primers tested on the accessions of $D$. microcarpum were developed on plant species belonging to the Solanaceae family with the aim of allowing their application in the study of the variability of chloroplast DNA in other species or families of Angiosperms (Bryan et al. 1999; Weising \& Gardner 1999). Region-specific amplification of D. microcarpum accessions cpDNA by these primers showed that genetic molecular markers developed in one species can be used in molecular studies of other species. However, the absence of amplification by some primers testifies to the limit of the universality of these primers as referred to, but above all the need to develop specific primers for each species of plant. This lack of amplification observed in the present study with certain primers was also observed in other species such as Vitis vinifera (Vitaceae), Helianthus annuus (Asteraceae), Dioscorea sp. (Dioscoreaceae) and Solenostemon rotundifolius (Lamiaceae) respectively by Imazio et al. (2006), Wills \& Burke (2006), Chaïr et al. (2005) and Nanema et al. (2010). According to Decroocq et al. (2004) and Nanema et al. (2010), the lack of amplification of cpDNA sequences is explained by the absence of the corresponding microsatellite region targeted by the primer on chloroplast DNA.

Spatial genetic structuring and phylogeny between D. microcarpum populations - Molecular studies based on chloroplast DNA (cpDNA) focus on the one hand, the study of the mechanisms that control its evolution and on the other hand, the use of its variation as a tool to study the genetic diversity of plant species (Grivet 2002). In Angiosperms, cpDNA is the most used in the study of phylogenetic relationships. Indeed, the small size of cpDNA, its abundance in the plant cell, its maternal single-parent inheritance and especially its conservative rate of evolution (no genetic mixing), make the chloroplast genome a privileged tool for phylogenetic studies (Ndoye 2001; Oueslati Bahri 2017). These properties of cpDNA and the characteristics of microsatellite markers make it possible to follow chloroplast gene flow and analyse the dynamics of genetic diversity of $D$. microcarpum at large time scales (Andrianoelina Andrianaivo 2009).

Loading [MathJax]/jax/output/CommonHTML/jax.js 
The highest values of the effective allele, the expected heterozygosity and allelic richness observed in the South Borgou phytogeographic district means that $D$. microcarpum has a dispersal capacity and a high degree of isolation in this population (Govindaraj et al. 2015). The relatively high value of the expected heterozygosity implies a high degree of dissimilarity within the species studied. Wright fixation index recorded in all the different populations are low $\left(F_{I S} \otimes 1\right)$. In addition, the $F_{I S}$ calculated in the Atacora Chain phytogeographic district is negative $\left(F_{I S} \otimes 0\right)$ and reflects excess heterozygosity. These low rates of Wright fixation index can be explained by the high rate of allofertilization and / or dissemination that exists between the different individuals of $D$. microcarpum in the same population even though the species is autogamous (Hutchinson et al. 1958). Indeed, the seeds of $D$. microcarpum are mainly disseminated by humans, monkeys (Cercopithecus spp.), Rabbits (Oryctolagus cuniculus), squirrels (Sciurus vulgaris), giant rats (Rattus spp.), Elephants (Loxodonta africana) (Amahowé et al. 2012; Agbo et al. 2019a). This confirms the value of the Wright differentiation index $\left(F_{S T}\right)$ which is $0.024\left(F_{S T} \otimes 0.05\right)$. Results of AMOVA indicated that $17.35 \%$ of the total genetic diversity was due to differences within populations, while $45.80 \%$ of the overall genetic diversity was a result of differences among the population. These relatively low values of variation may be justified by the reproductive system of the species (Luo et al. 2007; Hasibuzzaman et al. 2020) dispersion of the species among farmers (Ov et al. 2011), and evolutionary changes within the species. Haplotype diversity reflects the degree of difference among the haplotypes in each population. The low haplotype diversity is observed in the present study showed weak differentiation in populations of $D$. microcarpum. The permutation test revealed a higher value for $N_{S T}(0.462)$ than $\mathrm{G}_{\mathrm{ST}}(0.201)$, with $\mathrm{P}<0.05$, indicating a clear phylogenetic structure among the populations (Deng et al. 2020).

The presence of individuals belonging to different populations of $D$. microcarpum within the three haplotypes clusters could be justified by a probable common origin of these populations or the existence of gene flows between the different natural populations of the species. This finding could be explained by the flow of genes within individuals from one population to another. These results corroborate those of Fontaine et al. (2004) who have shown that gene flow leads to the exchange of genes (or their alleles) between different populations. This gene flow observed in $D$. microcarpum populations is due to the mode of dispersal of seeds (dissemination) and pollens (pollination) of the plant by various agents. According to Kouyaté (2005), the seeds of $D$. microcarpum are dispersed by wind (anemochory), animals such as mammals and birds (zoochory) and humans (anthropochory). Although the species is self-pollinating, it possesses a fraction of allogamy. Its flowers are pollinated by wind (anemogamy) and insects such as ladybugs, flies and bees (entomogamy). These various disseminators and pollinators contribute to a wide dispersion of seeds and pollens. This promotes a significant flow of genes within populations of the species. Indeed, the mode of seed dissemination and that of flower pollination are the main factors responsible for gene flow within a plant species (GerberDanjon 2006).

\section{Conclusion}

We found distinct patterns of genetic diversity at different spatial scales. The new genomic DNA isolation protocol from Detarium microcarpum obtained after optimization is efficient and can be used successfully on other woody plants. Analysis of cpDNA using microsatellite markers showed a relatively high level of genetic polymorphism in accessions of the species within phytogeographic districts. There is an existence of gene flow Loading [MathJax]/jax/output/CommonHTML/jax.js geographic districts. Our findings on the genetic structure and gene 
flow of $D$. microcarpum populations based on different spatial conditions are caused by evolutionary forces such as dispersal and pollination. This information is necessary for taking conservation measures for the species.

\section{Abbreviations}

AMOVA

Analysis of molecular variance

cpDNA

Chloroplastic DNA

CTAB

Cetyl Triammonium Bromide

GPS

Global Position System

MATAB

Mixed Alkyl Timethyl Ammonium Bromide

PCR

Polymerase Chain Reaction

PIC

Polymorphism Information Content

SSR

Simple sequence repeat

\section{Declarations}

\section{Acknowledgements}

The authors say their gratitude to the Ministry of Higher Education and Scientific Research (MESRS) of the Republic of Benin for having awarded the scholarship that allowed the completion of the PhD thesis which this article is an activity. We wish to express our gratitude to Mme Germaine Mahouwèna Avohou, Mr Aimé Malo Djèssou and Mr Brice Ahouansombo Badé for their contributions.

\section{Authors' contributions}

RIA designed the study, collected and analysed the data and drafted the manuscript. AAM, DM and RAD read the protocol and improved the manuscript drafted. PS helped me for the molecular analysis. CA validated the research project and significantly contributed to the manuscript. All authors have read and approved the final manuscript.

\section{Funding information}

Not applicable.

\section{Availability of data and materials}


The data sets supporting the conclusions of this article are included within the article.

\section{Conflict of interest}

The authors declare that they have no conflict of interest.

\section{Data Archiving Statement}

This research contains no data that requires submission to a public database. Population names of Detarium microcarpum collection come from samples collected and georeferenced by the corresponding author in phytogeographic districts (Table 2). The names and allele sizes of the 7 SSR loci used in this study are listed in Table 4. Primer sequences for the SSR markers can be found in the original publications, which are referenced within the materials and methods of the manuscript.

\section{References}

Adjahossou SGC, Gouwakinnou GN, Houéhanou DT, Sode Al, Yaoitcha AS, Houinato MRB, Sinsin B (2016) Efficacité des aires protégées dans la conservation d'habitats favorables prioritaires de ligneux de valeur au Bénin. Bois Forêts Trop 2:67-76

Adjé O, Achigan-Dako E, Agbangla C (2016) Optimizing genomic DNA isolation in pineapple (Ananas comosus I.). J Plant Breed Genet 4:11-18

Agbangla C, Ahanhanzo C, Tostain S, Dansi A, Daïnou O (2002) Evaluation de la diversité génétique par RAPD d'un échantillon de Dioscorea alata d'une région du Bénin, la sous-préfecture de Savè. J Rech Sci Univ Lomé 6:197-202

Agbo IR, Idohou R, Vihotogbé R, Missihoun AA, Dagba RA, Assogbadjo EA, Agbangla C (2019b) Spatio-temporal dynamics of suitable habitats for Detarium microcarpum Guill. \& Perr. (Caesalpiniaceae), a priority food tree species in Benin (West Africa). Model Earth Syst Environ 5:595-604. doi:10.1007/s40808-018-0550-x

Agbo IR, Missihoun AA, Dagba AR, Assogbadjo EA, Agbangla C (2018) Morphological variability of Detarium microcarpum Guill. \& Perr. (Caesalpiniaceae) in Benin, West Africa. AJRAF 1: 1-12.

doi:10.9734/AJRAF/2018/41234

Agbo IR, Missihoun AA, Vihotogbé R, Assogbadjo EA, Ahanhanzo C, Agbangla C (2017) Impacts des usages traditionnels sur la vulnérabilité de Detarium microcarpum Guill. \& Perr. (Caesalpiniaceae) dans le district phytogéographique Zou au Bénin. Int J Biol Chem Sci 11: 730-743. doi:10.4314/ijbcs.v11i2.16

Agbo IR, Vihotogbé R, Missihoun AA, Dagba AR, Assogbadjo EA, Agbangla C (2019a) Indigenous knowledge of Detarium microcarpum Guill. \& Perr. (Caesalpiniaceae) and implication for conservation in Benin (West Africa). Environ Dev Sustain 22:626-6285. doi:10.1007/s10668-019-00477-3 
Amahowé IO, Djossa AB, Adomou AC, Kabré AT, Sinsin B (2012) Vegetation structure and tree diversity in habitats exploited by elephants in Benin (West Africa). J Appl Biosci 58:4223-4233

Andrianoelina Andrianaivo 0 (2009) Diversité génétique, physiologie de reproduction et étude d'impact de la fragmentation sur Dalbergia monticola de la forêt orientale de Madagascar. Thèse. Université d'Antananarivo, Madagascar

Assogbadjo AE, Glèlè Kakaï R, Kyndt T, Sinsin B (2010) Conservation genetics of baobab (Adansonia digitata L.) in the Parklands Agroforestry Systems of Benin (West Africa). Notulae Botanicae Horti Agrobotanici ClujNapoca 38:136-140

Bataillon TM, David JL, Schoen DJ (1996) Neutral genetic markers and conservation genetics: Simulated germplasm collections. Genetics 114:409-417

Benbouza H, Baudoin JP, Mergeai G (2006) Amélioration de la méthode d'extraction d'ADN au CTAB appliquée aux feuilles de cotonnier. Biotechnol Agron Soc Environ 10:73-76

Benemann DP, Machado LN, Argel LWP, Bianchi VJ, Oliveira AC, Maia LC, Peters JA (2012) Identification, characterization and validation of SSR markers from the gerbera EST database. Plant Omics J 5:156-159

Bhandari HR, Bhanu AN, Srivastava K, Singh MN, Shreya A, Hemantaranjan A (2017) Assessment of genetic diversity in crop plants - an overview. Adv Plants Agric Res 7:279-286. doi:10.15406/apar.2017.07.00255

Bhattacharjee R, Bramel PJ, Hash CT, Kolesnikova-Allen MA, Khairwal IS (2002) Assessment of genetic diversity within and between pearl millet landraces. Theor Appl Genet 105:666-673

Botstein D, White RL, Skolnick M, Davis RW (1980) Construction of a genetic linkage map in man using restriction fragment length polymorphisms. Am J Hum Genet 32:314-331

Bryan GJ, McNicoll J, Ramsay G, Meyer RC, Jong WSD (1999) Polymorphic simple sequence repeat markers in chloroplast genomes of Solanaceous plants. Theor Appl Genet 99:859-867

Cavin AL (2007) Contribution à la connaissance taxonomique et chimique de fruits africains du genre "Detarium" (Fabaceae - Caesalpinioideae): "D. microcarpum" Guill. et Perr. et des formes comestibles et toxiques de "D. senegalense". J.F. Gmel Thèse, Université de Genève, Suisse

Chabi Sika K, Kefela T, Adoukonou-Sagbadja H, Ahoton L, Saidou A, Baba-Moussa L, Baptiste JL, Kotconi OS, Gachomo WE (2015) A simple and efficient genomic DNA extraction protocol for large scale genetic analyses of plant biological systems. Plant Gene 1:43-45

Chaïr H, Perrier X, Agbangla C, Marchand JL, Daïnou O, Noyer JL (2005) Use of cpSSRs for the characterisation of yam phylogeny in Benin. Genome 48:674-684

Creste S, Neto AT, Figueira A (2001) Detection of single sequence repeat polymorphisms in denaturing polyacrylamide sequencing gels by silver staining. Plant Mol Biol Rep 19:299-306 
Dagba AR, Missihoun AA, Sedah P, Agbo IR, Agbangla C (2018) Genetic Diversity of Cultivated Millet Varieties (Pennisetum glaucum (I.) R. Br.) in Benin Using Microsatellite Markers (SSRs) and Impact of Farmer's Practices on their Genetic Structuring. J Nat Prod Plant Resour 8: 23-40

de Cesare M, Hodkinson TR, Barth S (2010) Chloroplast DNA markers (cpSSRs, SNPs) for Miscanthus, Saccharum and related grasses (Panicoideae, Poaceae). Mol Breeding 26, 539-544 (2010).

https://doi.org/10.1007/s11032-010-9451-z

Decroocq V, Hagen LS, Favé M-G, Eyquard J-P, Pierronnet A (2004) Microsatellite markers in the hexaploid Prunus domestica species and parentage lineage of three European plum cultivars using nuclear and chloroplast simple-sequence repeats. Mol Breeding 13:135-142

Dellaporta SL, Wood J, Hicks JB (1983) A plant DNA mini preparation: Version II. Plant Mol Biol Rep 4:19-21

Deng Y, Liu T, Xie Y, Wei Y, Xie Z, Shi Y, Deng X (2020) High Genetic Diversity and Low Differentiation in Michelia shiluensis, an Endangered Magnolia Species in South China. Forests 2020, 11, 469; doi: 10.3390/f11040469

Doulougou B (2002) Les médicaments antirétroviraux et les molécules organiques antirétrovirales d’origine naturelle. Thèse. Université de Ouagadougou, Burkina Faso

Doyle JJ, Doyle JL (1987) A rapid isolation procedure for small quantities of fresh leaf tissue. Phytochem Bul $19: 11-15$

Dwivedi SL, Gurtu S, Chandra S, Yuejin W, Nigam SN (2001) Assessment of genetic diversity among selected groundnut germplasm I: RAPD analysis. Plant Breed 120:345-349

Ercisli S, Orhan E, Esitken A, Yildirim N, Agar G (2008) Relationships among some cornelian cherry genotypes (Cornus mas L.) based on RAPD analysis. Genet Res Crop Evol 55(4):613-618

Excoffier L, Lischer HE (2010) Arlequin suite ver 3.5: a new series of programs to perform population genetics analyses under Linux and Windows. Mol Ecol Resour 10:564 567. DOI 10.1111/j.1755-0998.2010.02847.x

Fontaine C, Lovett PN, Sanou H, Maley J, Bouvet J-M (2004) Genetic diversity of the shea tree (Vitellaria paradoxa C.F. Gaertn), detected by RAPD and chloroplast microsatellite markers. Heredity 93:639-648

Gerber-Danjon S (2006) Flux de gènes et arbres forestiers. Université Bordeaux Habilitation, France

Govindaraj M, Vetriventhan M, Srinivasan M (2015) Importance of Genetic Diversity Assessment in Crop Plants and Its Recent Advances: An Overview of Its Analytical Perspectives. Genet Res Int 2015:431487. doi:10.1155/2015/431487

Grivet D (2002) Phylogéographie et évolution moléculaire comparée d’arbres forestiers à l'aide des marqueurs chloroplastiques. Thèse. Université Henri Poincaré, Nancy-l, France

Hasibuzzaman, AS. M., Islam, A. A., Miah, M. G., \& Hasan, M. (2020). Phylogeographic diversity and population structure of Carica papaya L. revealed through nuclear microsatellites. Braz J Bot, 43(1), 147-154. 
Houédjissin SS (2016) Identification ethnobotanique et génétique de l'arbre à suif [Pentadesma butyracea Sabine (Clusiaceae)] en vue de sa domestication et de sa conservation au Bénin. Thèse. Université d'Abomeycalavi, Bénin

Houénon GHA, Djossou AJ, Kouhinkpo EY, Salako KV, Tchobo PF, Adomou CA, Yédomonhan H (2021) Parataxonomy, perceived dynamics and diversity of uses of two Detarium species in Benin (West Africa). Genet Resour Crop Evol 68:2627-2654. https://doi.org/10.1007/s10722-021-01169-6

Huda MN, Hasan M, Abdullah MH, Sarker U (2019) Spatial distribution and genetic diversity of wild date palm (Phoenix sylvestris) growing in coastal Bangladesh. Tree Genet Genomes 15:3. doi:10.1007/s11295-018-1310-9

Hutchinson J, Dalziel JM, Keay RWJ (1958) Flora of west tropical Africa, vol I, 2nd edn. The Whitefriars Press, London

Imazio S, Labra M, Grassi1 F, Scienza A, Failla O (2006) Chloroplast microsatellites to investigate the origin of grapevine. Genet Resour Crop Evol 53:1003-1101

Jahan T, Ali MA, Raihan MS, Rahman MM, Abdullah HM, Huda MN, Hasan M (2020) Indigenous Mota-named coarse rice germplasm is distinct from fine-grained rice collected from south-central coastal Bangladesh as compared with the morphological descriptors and molecular markers. Braz J Bot 43:933-945. https://doi.org/10.1007/s40415-020-00646-z

Karam MJ, Aouad M, Roig A, Bile A, Dagher-Kharrat BM, Klein KE, Fady B, Lefèvre F (2019) Characterizing the genetic diversity of Atlas cedar and phylogeny of Mediterranean Cedrus species with a new multiplex of 16 SSR markers. Tree Genet Genomes 15:60. doi:10.1007/s11295-019-1366-1

Konaté I (2007) Diversité Phénotypique et Moléculaire du Caroubier (Ceratonia siliqua L.) et des Bactéries Endophytes qui lui sont Associées. Thèse. Université Mohammed V-Agdal, Maroc

Kouyaté AM (2005) Aspects ethnobotaniques et étude de la variabilité morphologique, biochimique et phénologique de Detarium microcarpum Guill. \& Perr. Au Mali. Thèse. Université de Ghent, Belgique

Kouyaté AM, Van Damme P, De Meulenaer B, Diawara H (2009) Contribution des produits de cueillette dans l'alimentation humaine. Cas de Detarium microcarpum. Afrika focus 22:77-88

Kremer A (1994) Diversité génétique et variabilité des caractères phénotypiques chez les arbres forestiers. Gnt Sel Evol 26:105-123

Lakshmi M, Parani M, Parida A (2002) Molecular phylogeny of mangroves IX: Molecular marker assisted intraspecific variation and species relationships in the Indian mangrove tribe Rhizophoreae. Aquat Bot 74:201-217

Li Z, Nelson RL (2002) RAPD marker diversity among cultivated and wild soybean accession from Chinese provinces. Published in Crop Sci 42:1737-1744

Liu J, Sun ZX, Chen YT, Jiang JM (2012) Isolation and characterization of microsatellite loci from an endangered tree species, Toona ciliata var. pubescens. Genet Mol Res 11:4411-4417. doi:10.4238/2012

Loading [MathJax]/jax/output/CommonHTML/jax.js

Page $19 / 24$ 
Luo CW, Li K, Chen Y, Sun YY (2007) Floral display and breeding system of Jatropha curcas L. For Stud China 9:114-119

Ov I, Espinosa-García FJ, Nuntilde JS, Salvador-Figueroa M (2011) State of the art of genetic diversity research in Jatropha curcas. Sci Res Essays 6:1709-1719

Phumichai C, Phumichai T, Wongkaew A (2015) Novel Chloroplast Microsatellite (cpSSR) Markers for Genetic Diversity Assessment of Cultivated and Wild Hevea Rubber. Plant Mol Biol Rep 33:1486-1498.

https://doi.org/10.1007/s11105-014-0850-x

Mahmood N, Pizza C, Aquino R et coll (1993) Inhibition of VIH infection by flavonoïds. Antivir Res 22:189-199. doi: 10.1016/0166-3542(93)90095-Z

Missihoun AA, Adoukonou-Sagbadja H, Sedah P, Dagba AR, Ahanhanzo C, Agbangla C (2015) Genetic diversity of Sorghum bicolor (L.) Moench landraces from Northwestern Benin as revealed by microsatellite markers. Afric $\mathrm{J}$ of Biotech 14:1342-1353

Mongkolporn O, Kadkol GP, Pang ECK, Taylor WJ (2003) Identification of RAPD markers linked to recessive genes conferring siliqua shatter resistance in Brassica rapa. Plant Breed 122:479-484

Nacoulma-Ouedraogo OG (1996) Plantes médicinales et pratiques traditionnelles au Burkina Faso: cas du plateau central. Thèse. Université de Ouagadougou, Burkina-Faso

Nanema KR, Missihoun AA, Agbangla C, Ahanhanzo C, Traore ER, Bationo/Kando P, Sawadogo M, Zongo J-D (2010) Etude de la relation phylogénétique entre trois morphotypes de Solenostemon rotundifolius (Poir J. K. Morton) originaires du Burkina Faso par les marqueurs microsatellites chloroplastiques (SSRcp). Int J Biol Chem Sci 4:1922-1931

Ndoyé K (2001) La gestion des ressources génétiques au Sénégal: application au complexe d’espèce Acacia nilotica; Thèse. Université de Cheikh Anta Diop, Sénégal

Nikiema JB, Simpore J, Sia D, Djierro K, Guissou IP, Kasilo OMJ (2010) Introduction de plantes médicinales dans le traitement de l'infection à $\mathrm{VIH}$ : Une approche réussie au Burkina-Faso. The African Health Monitor. Decade of African traditional medicine, pp 2001-2010

Oueslati Bahri A (2017) Diversité et origine génétique des espèces de la sous famille des Aurantioideae et décryptage des structures interspécifiques des génomes des agrumes modernes. Thèse. Université de Tunis, Tunisie

Perrier X, Jacquemoud-Collet JP (2010) DARwin6.0. http://darwin.cirad.fr/darwin

Pons O, Petit RJ (1996) Measwring and testing genetic differentiation with ordered versus unordered alleles. Genetics 144:1237-1245

Sani A, Agunu A, Danmalam UH, Hajara I (2014) Pharmacognostic Studies of the Stem Bark of Detarium microcarpum - Guill. and Perr. (Fabaceae). Nat Prod Chem Res S1:004 doi:10.4172/2329-6836.S1-004 
Schenk FM, Thienpont C-N, Koopman MJW, Gilissen JWJL, Smulders MJM (2008) Phylogenetic relationships in Betula (Betulaceae) based on AFLP markers. Tree Genet Genomes 4:911-924. doi:10.1007/s11295-008-0162-0

Sun Y, Yang H, Zhang O, Qin L, Li P, Lee J, Chen S, Rahman K, Kang T, Jia M (2019) Genetic diversity and its conservation implications of Vitex rotundifolia (Lamiaceae) populations in East Asia. PeerJ. DOI $10.7717 /$ peerj. 6194

Vanijajiva O (2011) Genetic variability among durian (Durio zibethinus Murr.) cultivars in the Nonthaburi province, Thailand detected by RAPD analysis. J Agri Tech 7:1105-1114

Vihotogbé R, van den Berg RG, Missihoun AA, Sinsin B, Sosef MS (2015) Genetic diversity of bitter and sweet African bush mango trees (Irvingia spp., Irvingiaceae) in West and Central Africa. Afr J Biotechnol 14:30623074. doi:10.5897/AJB12.2564

Weising K, Gardner RC (1999) A set of conserved PCR primers for the analysis of simple sequence repeat polymorphism in chloroplast genome of dicotyledons angiosperms. Genome 42:9-19

Wills DM, Burke JM \& (2006) Chloroplast DNA variation confirms a single origin of domesticated sunflower (Helianthus annuus L.). Heredity 97:403-404

Wills DM, Hester ML, Aizhong L, Burke MJ (2005) Chloroplast SSR polymorphisms in the Compositae and the mode of organellar inheritance in Helianthus annuus. Theor Appl Genet 110:941-947. doi:10.1007/s00122004-1914-3

Wilson K, Walker J (2010) Principles and Techniques of Biochemistry and Molecular Biology. Cambridge University Press

Wright S (1978) Evolution and the genetics of populations. vol 4. Variability within and among Natural Populations. University of Chicago Press, USA

Yan Z, Denneboom C, Hattendorf A, Dolstra O, Debener T, Stam P, Visser PB (2005) Construction of an integrated map of rose with AFLP, SSR, PK, RGA, RFLP, SCAR and morphological markers. Theor Appl Genet 110:766-777. https://doi.org/10.1007/s00122-004-1903-6

Zeka D, Sedlak P, Sedlakova V, Sharma K, Vejl P (2015) Phenotype and molecular diversity evaluation of some wild 2n Solanum species (Super series Rotata). Chil J Agric Res 75:147-151

Zeka D, Sedlak P, Sedlakova V, Vasek J, Domkarova J, Vejl P (2014) CpDNA SSR polymorphism in secondary germplasm of potato maintained in cCzech gene bank. Pak J Agri Sci 51:743-748

\section{Figures}




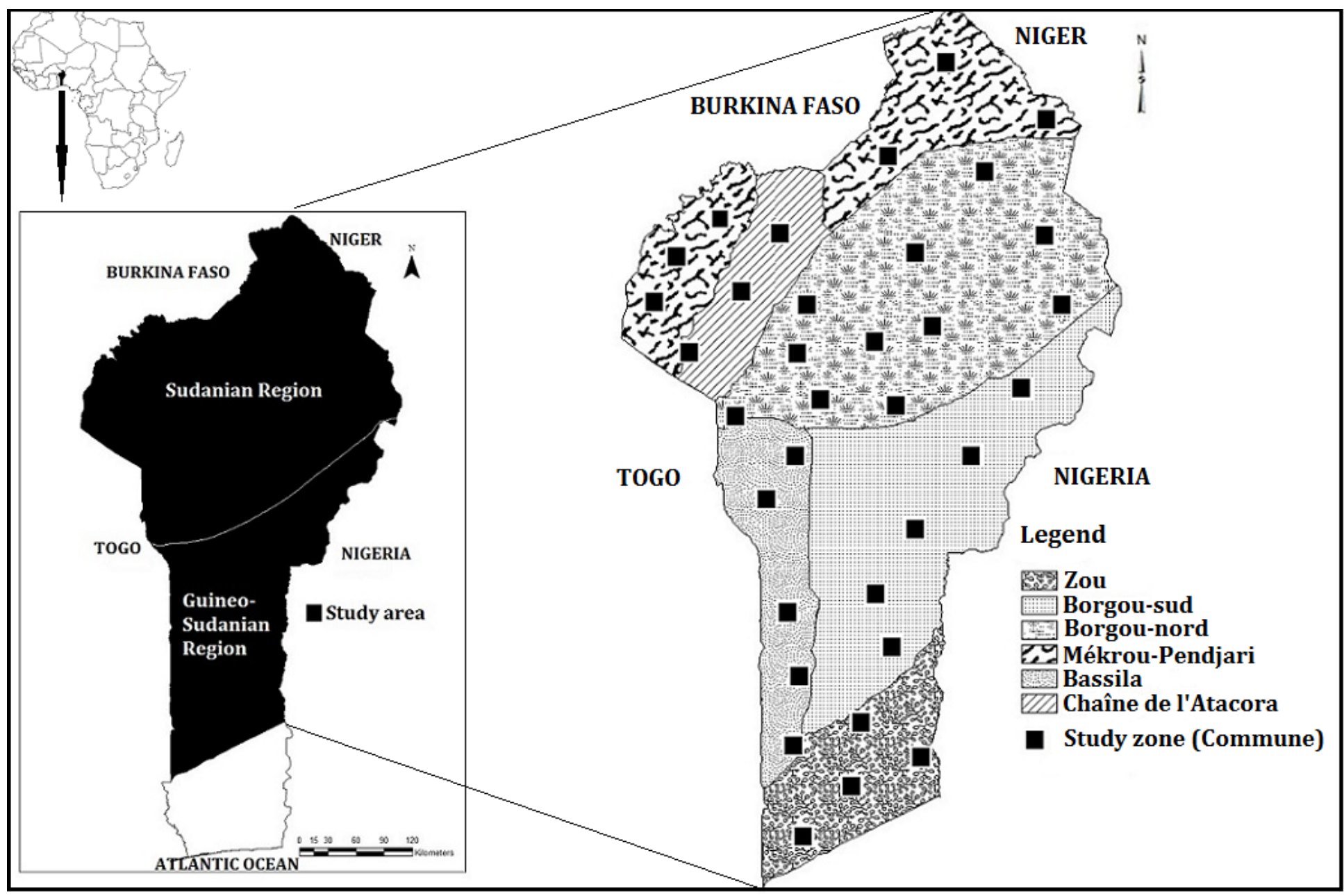

\section{Figure 1}

Map of Benin showing the location of sampling areas.

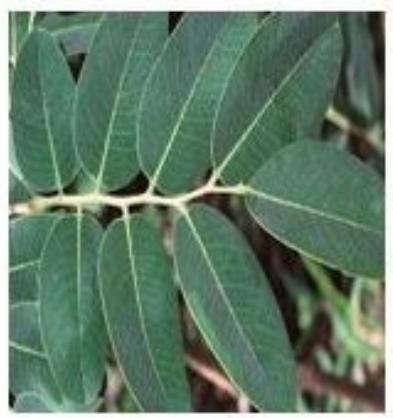

D. microcarpum leaves

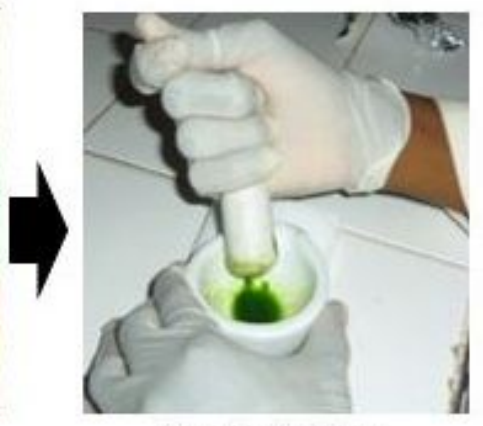

Leaf grinding

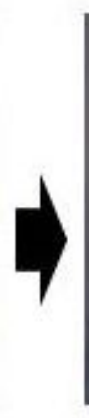

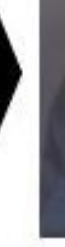

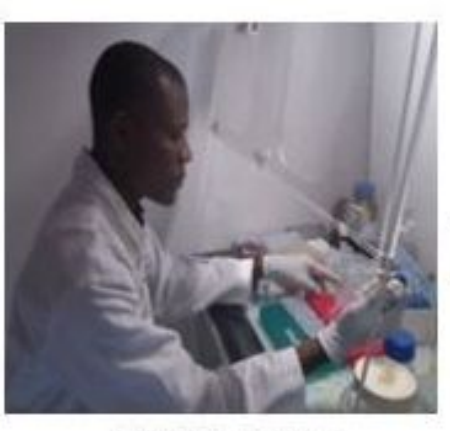

DNA isolation

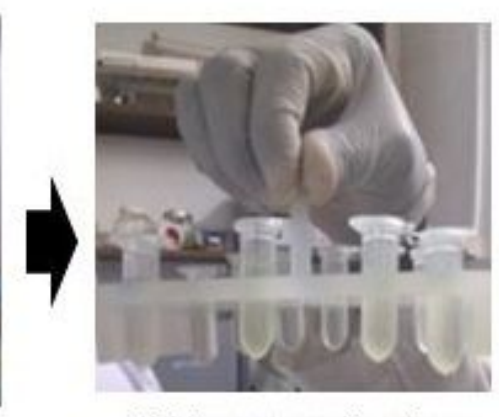

DNA extract in tubes

Figure 2

Some steps in the classic process of isolation Detarium microcarpum genomic DNA. 
Bands showing the presence of DNA

Agarose gel as DNA migration support

\section{Figure 3}

Analytical electrophoresis profiles on agarose gel of genomic DNA from some Detarium microcarpum samples.

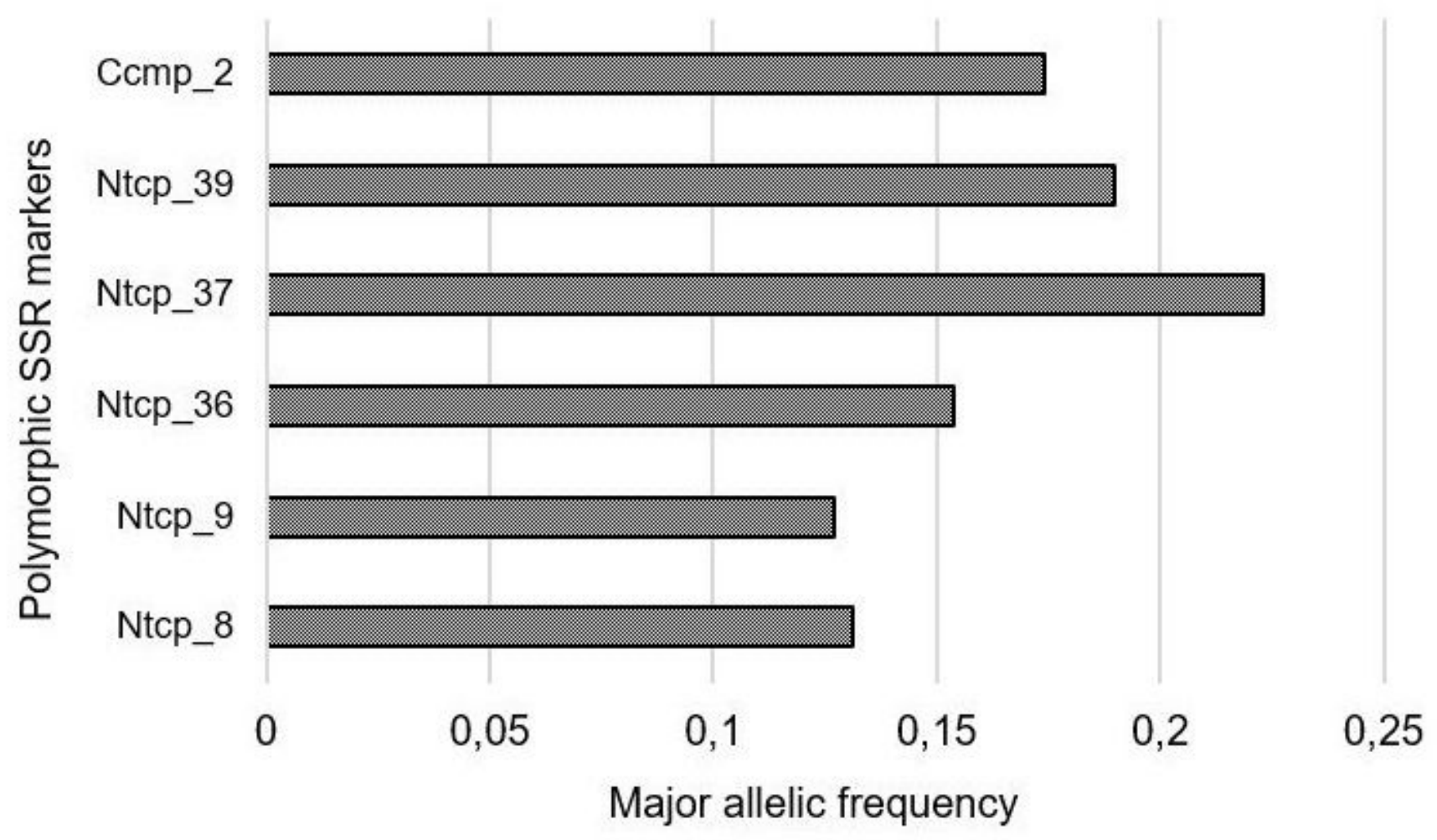

Figure 4

Major allelic frequency of polymorphic SSR marker. 


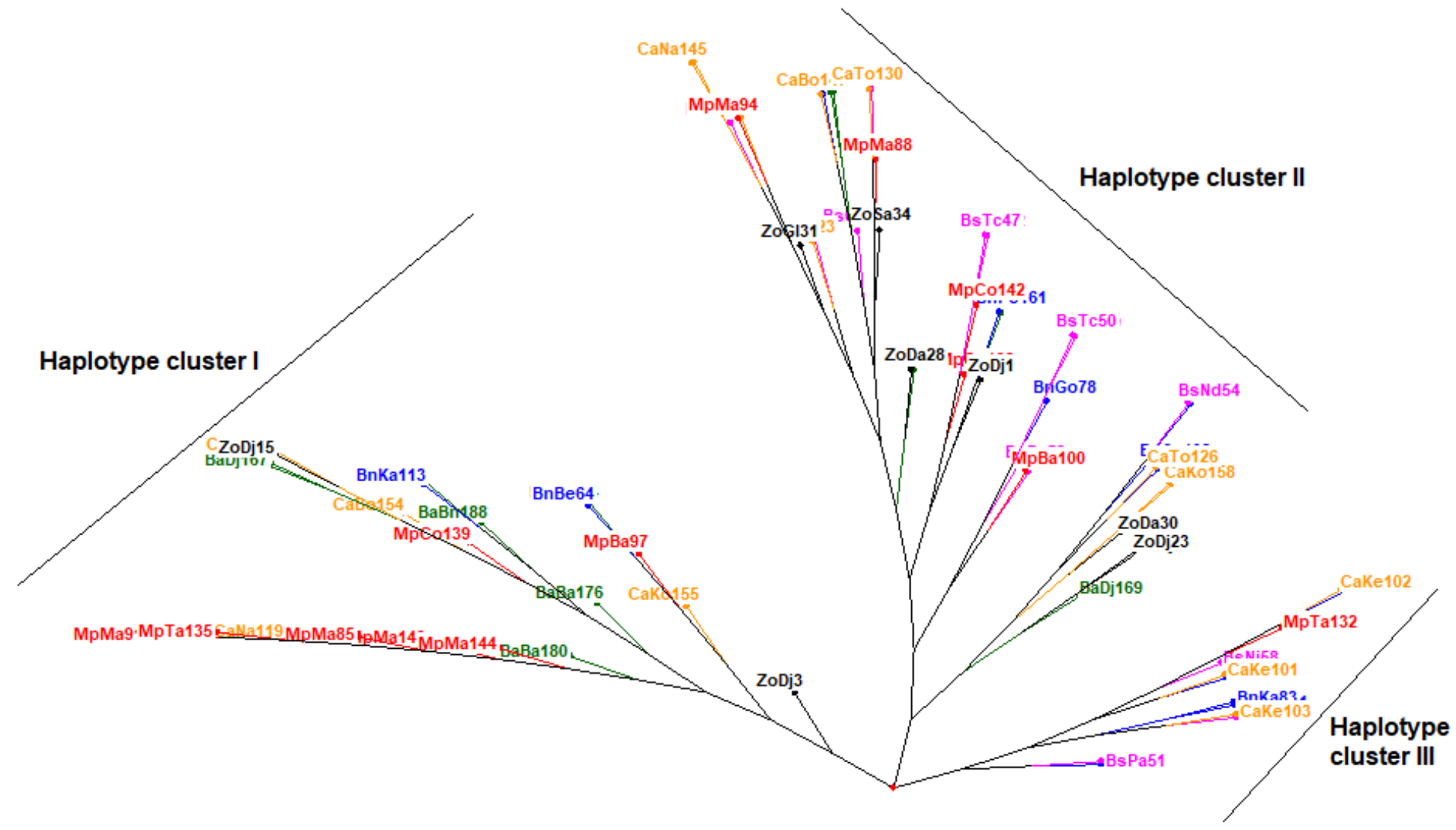

Figure 5

Neighbor-joining phylogenetic tree showing haplotypes clusters from Detarium microcarpum populations. Codes written with the same colour represent individuals of D. microcarpum belonging to the same population. 